\title{
アルミナ膜をプロトン伝導体に応用した 単室型燃料電池の特性評価*
}

野阪 英彦*1·吉村祐太郎*1 ·平野＼cjkstart俊*1 ·長田 昭義*1

\section{Operating Temperature Property of Single Chamber Fuel Cell Appling an Alumina Evaporated Film to Proton Conductor}

\author{
Hidehiko NOSAKA*1, Yutaro YOSHIMURA*1, Suguru HIRANO*1 and Akiyoshi NAGATA*1 \\ *1 Osaka Institute of Technology, 5-16-1 Omiya, Asahi-ku, Osaka 535-8585
}

(Received October 28, 2009, Accepted March 9, 2010)

\begin{abstract}
The performance of a single chamber fuel cell (SCFC) using a novel boehmite proton conductor as the inorganic electrolyte film is studied on operating temperatures from room temperature (RT) to $120^{\circ} \mathrm{C}$ in the dry gas mixtures of hydrogen and oxygen. The boehmite electrolyte film generated by the soaked treatment of the alumina evaporated film using the autoclave apparatus. The open circuit voltage (OCV) of SCFC using the Pt only electrodes obtained $300-350 \mathrm{mV}$ at operating temperatures between $\mathrm{RT}$ and $70^{\circ} \mathrm{C}$ in the dry gas mixtures, and however the OCV decreased at operating temperatures until $120^{\circ} \mathrm{C}$. On the other hand, the $\mathrm{OCV}$ of $\mathrm{SCFC}$ using the $\mathrm{Pt} / \mathrm{CB}$ electrodes was achieved $800 \mathrm{mV}$ at $\mathrm{RT}$ operation that this value corresponded to a development index of polymer electrolyte fuel cell.
\end{abstract}

\section{1. はじめに}

家庭用や自動車用の燃料電池が実用化されつつあり，エコ ロジーな発電装置として期待されている。しかし，室温で作 動する固体高分子形燃料電池 (PEFC) は固体電解質にフッ 素系ポリマーのプロトン伝導性有機高分子膜を用いるために, $80^{\circ} \mathrm{C}$ 程度が作動限界となり，その上湿度管理が必要不可欠 である11. 今後, 燃料電池の広汎な普及には, 電池システム の高出力密度化抢よび低コスト化が必須であり, 廃熱の利用 や電極への貴金属触媒の低減などを考えると, より高温（特 に100〜 200ㅇ間）で，かつ低加湿さらには無加湿で作動 可能なプロトン伝導性電解質の開発が切望されている.

そこで我々はPEFCのポリマーの代替として, 工業分野 などに幅広く利用され地球上に豊富な無機材料資源のアルミ ナ $\left(\mathrm{Al}_{2} \mathrm{O}_{3}\right)$ 素材を用いて, プロトン伝導を発現するべーマ イト $(\mathrm{AlO}(\mathrm{OH}))$ 膜 2 を生成して, 無加湿で高温作動する 燃料電池の開発を行っている. ベーマイトはボーキサイト中 に多く含まれており，人工的にはアルミナやアルミニウムを $200^{\circ} \mathrm{C}$ 以上の熱水中で浸漬処理によって生成でき, 化学的安 定性・耐熱性が高く, $500^{\circ} \mathrm{C}$ 付近まで脱水反応が起こらない 特長をもっている ${ }^{3)}$. 我々はアルミナ蒸着膜を出発素材とし たベーマイト膜を無機プロトン伝導体に応用することで, PEFCよりも安価で耐熱性および耐久性に優れた燃料電池の 作製およびその実用化を目指している，本報告では，真空蒸 着法を用いてアルミナ膜を成膜し, オートクレーブ装置を用 いて熱水・浸漬処理を行ってプロトン伝導性ベーマイト電解 質を生成した。生成したベーマイト電解質を単室型燃料電池 (SCFC) に応用して, 水素と酸素の無加湿混合ガス中で室 温 $(\mathrm{RT}) \sim 120^{\circ} \mathrm{C}$ の作動温度において電池性能を評価した ${ }^{4,5)}$.

* 平成 21 年 11 月 6 日 第50回真空に関する連合講演会で発表

*1 大阪工業大学工学部電気電子システム工学科 (下535-8585 大 阪市旭区大宮 5-16-1)

\section{2. ベーマイト電解質膜を用いた SCFC 単セルの 作製}

ベーマイト電解質膜の出発素材となるアルミナ膜は, $\alpha-$ $\mathrm{Al}_{2} \mathrm{O}_{3}$ 粉末 (キシダ化学製) を加圧形成して $1600^{\circ} \mathrm{C}$ で 5 時間 焼成した蒸着材料を, Pt 電極上に真空蒸着法によって約 3 $\mu \mathrm{m}$ を成膜した. $\mathrm{Pt}$ 電極は, $1.5 \mathrm{~cm}$ 角の無孔質アルミナ (ニラコ製）を支持基体として Ptペースト（田中貴金属製） を $1 \mathrm{~cm}^{2}$ の正方形になるように塗布し， $1000^{\circ} \mathrm{C}$ で焼成して 作製した. 次に, Pt 電極上に成膜したアルミナ膜を空気雾 囲気中 $500^{\circ} \mathrm{C}$ で焼成して, オートクレーブ装置を用いて 200 ${ }^{\circ} \mathrm{C}$ の熱水中で10時間の浸漬処理を行って, ベーマイト電解 質膜を生成した．さらに，多孔質アルミナ（ニッカトー製） 基板上にPtペースト（田中貴金属製）を一様に塗布して $1000^{\circ} \mathrm{C}$ で焼成した多孔質 $\mathrm{Pt}$ 電極をべーマイト電解質膜に接 触させ, クリップを用いて固定して SCFC 単セルを作製し た. また, 電極の触媒活性の違いを調べるために, Pt 単体 電極よりも触媒活性の高い $\mathrm{Pt} / \mathrm{CB}$ 電極を用いた単セルを作 製した. $\mathrm{Pt} / \mathrm{CB}$ 電極は, $1 \mathrm{~cm}$ 角のカーボンシート（東レ秼

(a)

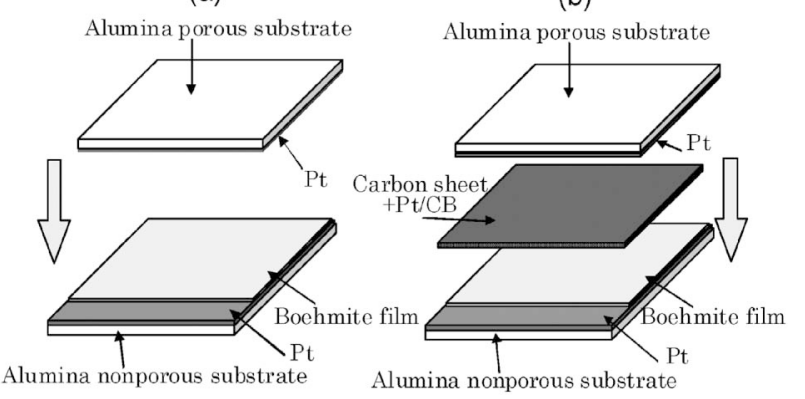

Fig. 1 Schematic diagrams of SCFC using boehmite electrolyte and (a) Pt and (b) Pt/CB electrodes, which can operate at RT to $120^{\circ} \mathrm{C}$ in the dry gas mixtures. 
製）に純水中 $1 \mathrm{~g} / \mathrm{L}$ の $\mathrm{Pt} / \mathrm{CB}$ （田中貴金属製）分散液を, $71 \mu \mathrm{L}$ を一様に滴下して作製した ${ }^{6)}$.2つの SCFC 単セルの 模式図を Fig. 1 に示す.

\section{3. 実 験 結 果}

\section{1 ベーマイト電解質膜の微細・結晶構造}

アルミナ蒸着膜から生成したベーマイト膜の生成相の同定 抢よび微細・結晶構造は走査型電子顕微鏡（SEM）観察お よび X 線回折（XRD）測定を用いて調べた.

熱水・浸漬処理前と処理後の XRD 結果を Fig. 2 に示 す。また，ベーマイト粉末（和光純薬工業侏製） $1 \mathrm{~g}$ を1020 $\mathrm{kg} / \mathrm{cm}^{2}$ の圧力で一軸加圧成形したベーマイトペレットの
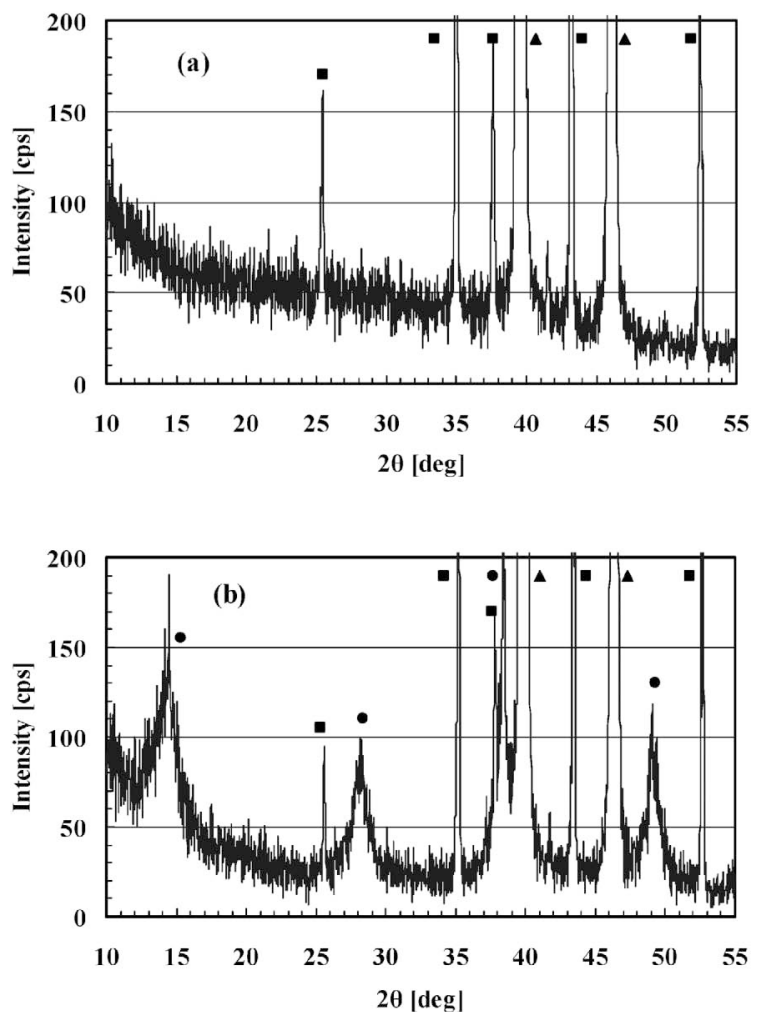

Fig. 2 XRD patterns of (a) as-deposited alumina film and (b) alumina film soaked during 10 hours in hot water of $200^{\circ} \mathrm{C}$. In figure, symbol of $\bullet$ shows a diffraction peak of $\mathrm{AlO}(\mathrm{OH})$, is ones of $\mathrm{Al}_{2} \mathrm{O}_{3}, \boldsymbol{\Delta}$ is ones of $\mathrm{Pt}$.

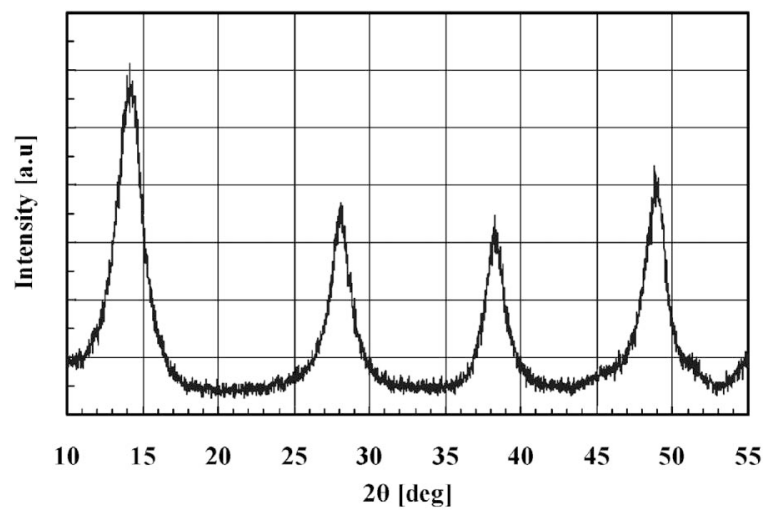

Fig. 3 XRD pattern of the boehmite pellet.
XRD パターンを Fig. 3 に示す.オートクレーブ装置を用い て $200^{\circ} \mathrm{C} て ゙ 10$ 時間の熱水・浸漬処理を行うことにより，処理 前には見られなかった $14,28,38,49$ 度付近の回折ピーク（図 中の・）が顕著に出現した. 4 つの回折ピークはベーマイト ペレットと同様の回折ピークであることがわかった.

次に，SEMによりベーマイト膜の表面，断面の微細構造 を観察した。Fig. 4, Fig. 5 は表面，断面の SEM 観察をそ れぞれ示している. $200^{\circ} \mathrm{C}$ 熱水中で 10 時間の浸漬処理を行 うことにより, ベーマイト膜表面が角張った粒子状に変化し た. 断面観察では, 浸漬処理後は粒子が集合し固まって膜形 成しているように見えた。 また，処理前の膜厚が約 $3 \mu \mathrm{m}$ で あったが，処理後は約 $3.6 \mu \mathrm{m}$ とべーマイト膜が厚くなって いた．これは，アルミナ膜を熱水・浸漬処理することによっ て，膜中に過㮃の水が入り含水量が多くなり，親水性に優れ たベーマイト層に変化して膜厚が増加したと考えられる．結 果として，真空蒸着によって成膜したアルミナ膜をオートク レーブ装置で熱水・浸漬処理することによって，燃料電池用 電解質のベーマイト膜を生成できることが確認できた.

\subsection{SCFC 単セルの作動温度特性}

ベーマイト電解質膜にPt 電極を取り付けて作製した SCFC 単セルの作動温度特性を調べた。 Fig. 6 は室温から $120^{\circ} \mathrm{C}$ まで変化させて測定した開回路電圧 $(\mathrm{OCV})$ 特性を示 している。ここで，水素ガス流量を $50 \mathrm{ml} / \mathrm{min}$ ，酸素ガス流 量を $25 \mathrm{ml} / \mathrm{min}$ に固定し，ガスブレンダー装置を用いて乾燥 混合ガスを供給した. SCFC 単セルの OCV は無加湿混合ガ ス中で作動温度 $50^{\circ} \mathrm{C} に$ おいて最大 $346 \mathrm{mV}$ を得ることができ た. 電極の極性は多孔質 $\mathrm{Pt}$ 電極がアノードとなり，アルミ
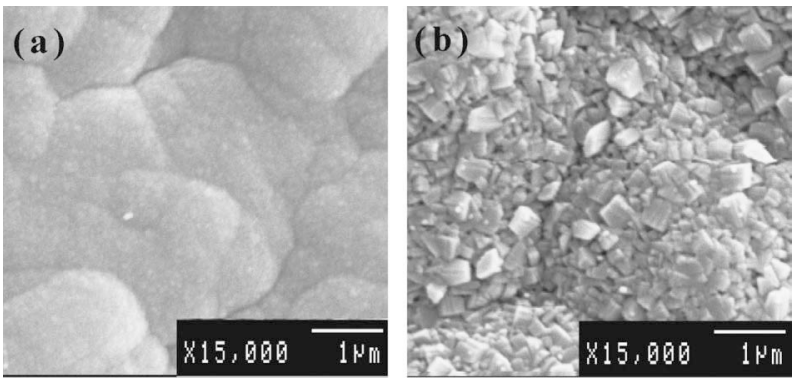

Fig. 4 Surface SEM micrographs of (a) as-deposited alumina film and (b) alumina film soaked during 10 hours in hot water of $200^{\circ} \mathrm{C}$.
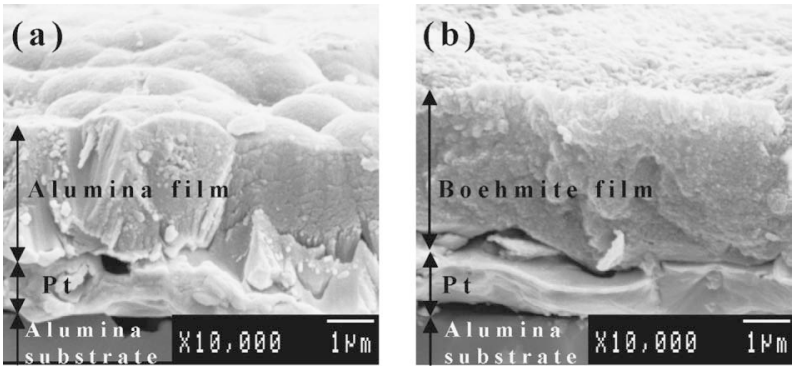

Fig. 5 Cross-sectional SEM micrographs of (a) as-deposited alumina film and (b) alumina film soaked during 10 hours in hot water of $200^{\circ} \mathrm{C}$. 


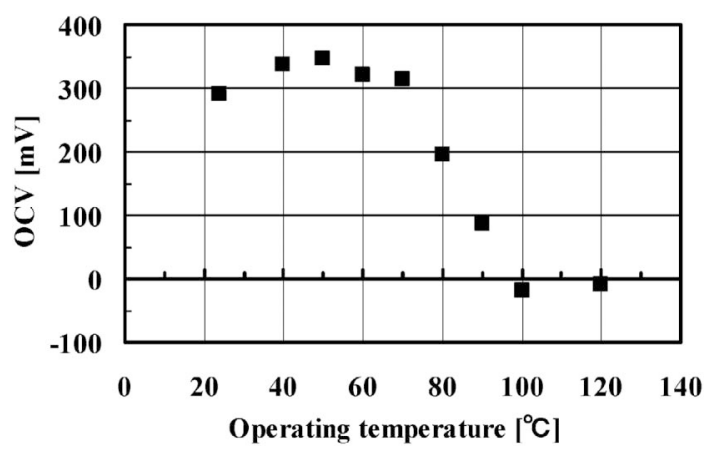

Fig. 6 OCV property of SCFC using boehmite electrolyte and $\mathrm{Pt}$ electrode at operating temperatures from RT to $120^{\circ} \mathrm{C}$ in the dry gas mixtures.

ナ膜を成膜した無孔質 $\mathrm{Pt}$ 電極がカソードとなった。これは 多孔質 $\mathrm{Pt}$ 電極に混合ガスが多く拡散して Pt 電極上に水素 が解離吸着して水素酸化反応7)が促進され，アノードとして 機能したと考えられる。 また，作動温度 $70^{\circ} \mathrm{C}$ までは安定し

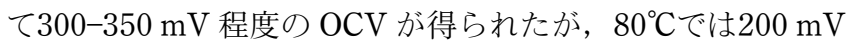
まで減少し，その後作動温度の上昇と共に OCV が減少する

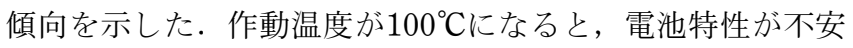
定となり極性が反転した。

結果として, ベーマイト電解質膜は耐熱性と親水性に優れ たプロトン伝導体で, $500^{\circ} \mathrm{C}$ 付近まで脱水反応が起こらな (3)ので，作動温度の上昇による電解質膜の劣化によって OCV が減少したとは考えにくい。従って, $80^{\circ} \mathrm{C}$ 以上の作動 温度に抢ける OCV の減少抢よび不安定な電池特性は電解質 膜を $\mathrm{Pt}$ 電極で挟み込んでクリップで固定した構造に起因し て抢り，作動温度の上昇と共に Pt 電極と電解質膜の接触が 弱くなり, 電極触媒反応が局部的に不十分となって不安定な 電池特性を示したと考えられる. 今後, SCFC のセル構造や 電極構造の改善が必要である.

\section{$3.3 \mathrm{SCFC}$ 単セルの触媒電極による負荷特性}

前述したように, ベーマイト電解質膜と Pt 電極単体を使 った SCFC 単セルの室温における $\mathrm{OCV}$ は $300 \mathrm{mV}$ 程度と理 論起電力よりも小さい值であった。 これは, ベーマイト電解 質膜の劣化ではなく, セル構造や触媒電極の違いが電池性能 に影響したと考えられる。そこで, $\mathrm{Pt}$ 電極単体と $\mathrm{Pt} / \mathrm{CB}$ 触 媒電極を使用して, 触媒活性による SCFC 単セルの室温作 動特性について調べた. Fig. 7 は Pt 電極単体を用いて測定 した単セルの端子電圧-電流密度特性（V-I 特性）を示して いる. Pt 電極単体の場合には, OCV は最大 $300 \mathrm{mV}$ で負荷 電流はほとんど得ることができなかった。一方, $\mathrm{Pt} / \mathrm{CB}$ 触 媒電極を用いて測定した V-I 特性を Fig. 8 に示す.カーボ ンシートを拡散層とした $\mathrm{Pt} / \mathrm{CB}$ 電極を用いることによって, OCV が最大 $800 \mathrm{mV}$ まで増加でき, ほぼ理論起電力1) に近い 值が達成できた。この值は PEFC の開発指標8である.ささ には, 負荷電流は Pt 電極単体を取り付けて室温で作動させ た場合に比べると200倍近い大きな電流密度が得られた。

$\mathrm{Pt}$ 電極単体では電極/電解質の界面に抢汀電極反応によ る抵抗の増大によって, 外部電流がほとんど得ることができ なかった。一方, カーボンシートを拡散層とした $\mathrm{Pt} / \mathrm{CB}$ 触

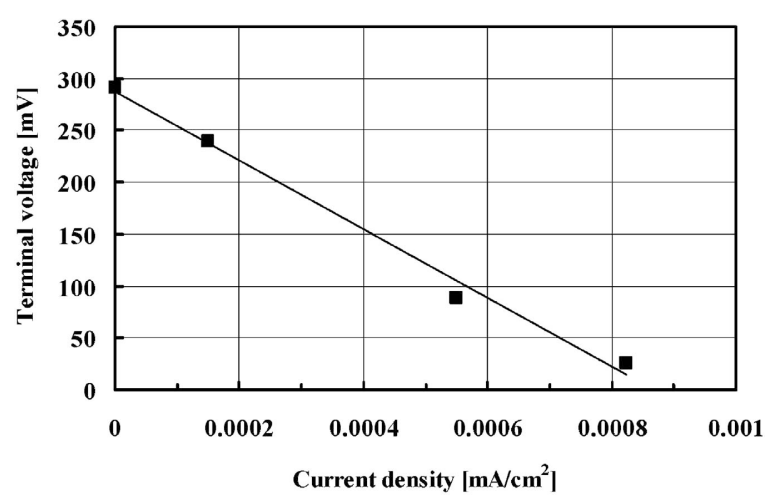

Fig. 7 V-I property of SCFC using boehmite electrolyte and Pt electrode at room temperature in the dry gas mixtures.

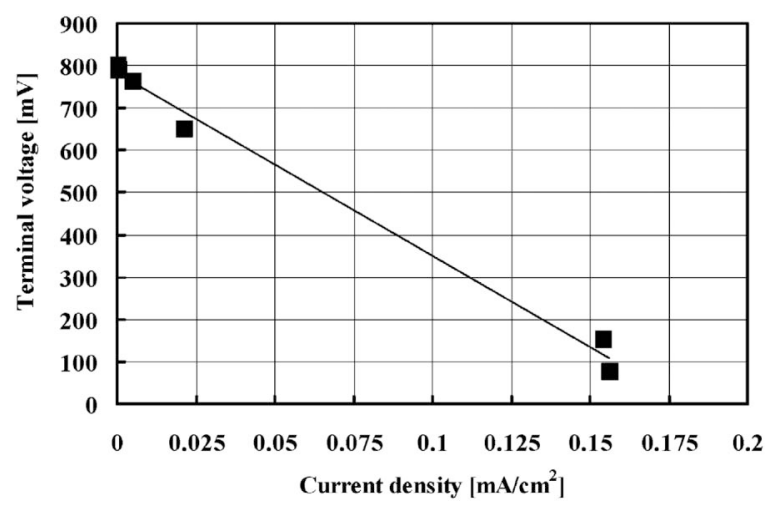

Fig. 8 V-I property of SCFC using boehmite electrolyte and $\mathrm{Pt} / \mathrm{CB}$ electrode at room temperature in the dry gas mixtures.

媒電極によって，アノードに扔ける触媒活性が大きくなり電 極反応に起因した活性化過電圧を低減でき, 負荷電流が増加 したと考えられる1,8).したがって, PEFC と同じような触 媒電極材料を用いることによって, SCFC の電極/電解質の 界面に抢ける触媒活性が増大でき, SCFC 単セルの電池性能 を大きく改善できることが確認できた.これらの結果から， ベーマイト膜は燃料電池用プロトン伝導性電解質として十分 に適用できると言える.しかしながら, SCFC 単セルの電流 密度は開発指標よりも低い値を示したので, 活性化過電圧を より低減するために, 電解質膜と電極を一体化した膜電極接 合体（MEA）構造にするなどの改良が必要である.

\section{4. おわりに}

$\mathrm{Pt}$ 電極上に真空蒸着によって成膜したアルミナ膜を, オートクレーブ装置で熱水・浸漬処理して, プロトン伝導性 ベーマイト電解質膜を生成した. 生成したベーマイト電解質 を応用した単室型然料電池 $(\mathrm{SCFC})$ を作製し, 水素々酸素 の無加湿混合ガス中で室温から $120^{\circ} \mathrm{C}$ 作動温度において電 池性能を評価した。 また, 触媒電極材料の違いによる SCFC 単セルの負荷特性である端子電圧-電流密度特性（V-I 特性） を調べることによって, 以下のことがわかった．

1）オートクレーブ装置を用いてアルミナ蒸着膜を $200^{\circ} \mathrm{C}$ で熱水・浸漬処理を行うことで, プロトン伝導性電解質とし 
てのベーマイト膜が生成できることが XRD と SEM 観察に よって確認できた. SEM 観察では, 浸漬処理後のベーマイ 卜膜が成膜したアルミナ膜よりも膜厚が増加していた。これ は, 浸漬処理によって膜中に水が入り含水量が多くなり, 親 水性に優れたベーマイト層が生成されて膜厚が増加したと考 えられる。

2) Pt 電極単体を用いた SCFC 単セルの無加湿混合ガス 中の作動温度特性を測定した結果, 開回路電圧 (OCV) は 作動温度 $50^{\circ} \mathrm{C}$ のとに最大 $346 \mathrm{mV}$ が得られた。 また, 単セ ルは室温から $70^{\circ} \mathrm{C}$ な゙は安定した発電特性を示したが，80

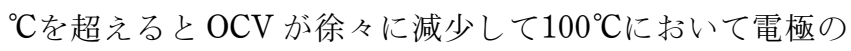
極性が反転した. $80^{\circ} \mathrm{C}$ 以上の作動温度に抢ける OCV の減少 は, ベーマイト電解質膜の劣化によるものではなく, 触媒電 極構造に起因していると考えられる。つまり, 電解質膜を $\mathrm{Pt}$ 電極で挟み込んでクリップで固定した電池構造としたこ とで, 作動温度の上昇と共に $\mathrm{Pt}$ 電極と電解質膜との接触が 弱くなり, 電極触媒反応が局部的に不十分となって不安定な 発電特性を示したと考えられる.

3） $\mathrm{Pt} / \mathrm{CB}$ 触媒電極を用いることで OCV が最大 $800 \mathrm{mV}$ まで増加でき, ほぼ理論起電力に近い值が達成できた.さら には, 負荷電流も $\mathrm{Pt}$ 電極単体の場合に比べて 200 倍近く増
加できた．これは $\mathrm{Pt} / \mathrm{CB}$ 電極を使用することで触媒活性が 大きくなり, 電極反応に起因した活性化過電圧を低減でき, 負荷電流が増加したと考えられる。

4）アルミナ蒸着膜の浸漬処理によるベーマイト電解質 膜の有用性および触媒電極材料による電池性能の向上が確認 できたので, 今後はホットプレス法, スパッタ法を用いて電 解質膜と電極を一体化した膜電極接合体（MEA）構造のセ ルスタックを作製して, 無加湿混合ガス中で $100^{\circ} \mathrm{C}$ 以上の高 温作動に打ける電池性能の向上を図り，PEFCに替わる SCFCの高エネルギー密度化を進めて行く予定である.

\section{〔文献〕}

1) "Fuel cell and polymers", (The Society of Polymer Science, Japan), (Kyoritsu Shuppan Co. Ltd., 2006) [in Japanese].

2) C. K. Dyer: Nature, 343(8) (1990) 547.

3) K. Tanabe, T. Kiyoyama and K. Fueki: Metal oxide and composite oxide (Kodansya Ltd., 1978) pp. 72-74 [in Japanese].

4) T. Kimura and A. Nagata: Shinku, 50 (2007) 175 [in Japanese].

5) A. Nagata, H. Nosaka, Y. Yoshimura and T. Kimura: IEEJ Trans., 3 (2008) 569.

6) Tokkai 2006-220538 [in Japanese].

7) T. Kobayashi: Shinku, 49 (2006) 2 [in Japanese].

8) H. Tagawa: Solid oxide fuel cell and earth environment (Agune Center, 1998), pp. 57-59 [in Japanese]. 